\title{
PENGARUH SERVICESCAPE TERHADAP KEPUASAN PENGUNJUNG BULELENG FESTIVAL DI KABUPATEN BULELENG
}

\author{
I Nengah Wirata \\ Program Studi Manajemen Konvensi dan Perhelatan,Politeknik Pariwisata Bali \\ Jl. Darmawangsa, Kampial Nusa Dua Bali \\ atastp@yahoo.com
}

\begin{tabular}{l|l|l} 
Received: Agustus, 2020 & Accepted: September, 2020 & Published: September, 2020
\end{tabular}

\begin{abstract}
The tourism sector is a mainstay sector that contributes or contributes significantly financially to the business activities of festival events in Bali Province. One of the districts that has carried out festival activities several times and has interesting natural and cultural attractions is Buleleng Regency. The Buleleng Regency Government holds festival events, one of which is the Buleleng Festival. The holding of the Buleleng Festival is a representation of bringing back local culture that can evoke the identity of Buleleng Regency. The local culture of Buleleng Regency is applied in a form of festival event activities. One of the festival events that is attractive to visitors' choice is the Buleleng festival. The Buleleng festival is a festival event that prioritizes attractive event design and concepts. The increasing number of festival events that are being held in Buleleng Regency, requires event planners and managers to have creative, innovative imaginations in presenting the concept of events by paying attention to various servicescapes and activities to increase the attraction and interest of visitors. The research objective is to examine how servicescape influence the visitor satisfaction of Buleleng festival. The number of samples used was 90 respondents with purposive sampling technique. Data processing was used with multiple linear regression analysis in the SPSS version 20 program. The results showed that there was a partial positive relationship with the atmosphere dimension, namely 0.570, the design dimension, 0.477 , and the social dimension, 0.617, to visitor satisfaction. And simultaneously, from the atmosphere dimension, design dimension and social dimension that have been implemented in the Buleleng festival event on visitor satisfaction, it has a strong relationship, which is equal to 0.728.
\end{abstract}

Keywords: servicescape, festival event, visitor satisfaction

\begin{abstract}
Abstrak
Sektor pariwisata merupakan sektor andalan yang memberikan kontribusi atau sumbangan secara finansial yang cukup besar dalam aktivitas bisnis event festival di Provinsi Bali. Salah satu Kabupaten yang sudah beberapa kali melaksanakan kegiatan festival dan memiliki daya tarik alam dan budaya yang menarik adalah Kabupaten Buleleng. Pemerintah Kabupaten Buleleng menyelenggarakan event festival yaitu salah satunya Buleleng Festival. Diadakannya Buleleng Festival merupakan suatu representasi akan mengangkat kembali budaya lokal yang dapat membangkitkan jati diri Kabupaten Buleleng. Budaya lokal Kabupaten Buleleng diaplikasikan dalam suatu bentuk kegiatan event festival. Salah satu
\end{abstract}


event festival yang menjadi menarik untuk menjadikan pilihan pengunjung adalah Buleleng festival. Buleleng festival merupakan event festival yang mengutamakan desain dan konsep event yang menarik. Semakin banyaknya event festival yang dilaksanakannya di Kabupaten Buleleng, menuntut para perencana dan pengelola event akan memiliki imajinasi yang kreatif, inovatif dalam menampilkan konsep event dengan memperhatikan servicescape dan kegiatan yang beranekaragam untuk meningkatkan daya tarik dan minat pengunjung. Adapun tujuan penelitian adalah untuk mengkaji bagaimana pengaruh servicescape terhadap kepuasan pengunjung Buleleng festival. Jumlah sampel yang digunakan adalah sebanyak 90 responden dengan teknik purposive sampling. Pengolahan data yang digunakan dengan analisis regresi linier berganda pada program SPSS versi 20. Hasil penelitian menunjukkan terdapat hubungan positif secara parsial pada dimensi suasana yaitu 0,570, dimensi disain yaitu 0,477 dan dimensi sosial yaitu 0,617 terhadap kepuasan pengunjung. Dan secara simultan dari dimensi suasana, dimensi disain dan dimensi sosial yang telah diimplementasikan dalam event Buleleng festival terhadap kepuasan pengunjung memiliki hubungan yang kuat yaitu sebesar 0,728.

\section{Kata Kunci: Servicescape, Event Festival, Kepuasan Pengunjung}

\section{PENDAHULUAN}

Perkembangan sektor pariwisata khususnya bisnis event di Provinsi Bali pada umumnya mengalami peningkatan yang sangat pesat, seiring berkembanganya pembangunan diberbagai sektor perekonomian. Sektor pariwisata merupakan sektor andalan yang memberikan kontribusi atau sumbangan secara finansial yang cukup besar terhadap tingkat pertumbuhan ekonomi daerah Bali, sehingga perlu terus dikembangkan, sesuai dengan kondisi, potensi alam dan budaya yang dimiliki oleh kawasan wisata. Potensi dan sumberdaya lainnya yang dimiliki oleh masing-masing kawasan wisata, tersebar di semua Kabupaten yang ada di Bali sesuai dengan karakteristik daerahnya.

Salah satu wilayah di Bali yang kian gencar mempromosikan diri melalui special event adalah Kabupaten Buleleng. Kabupaten yang terletak di bagian utara Bali tersebut kini semakin berkembang seiring dengan terciptanya destinasi wisata baru dan berbagai perhelatan yang diselenggarakan. Upaya-upaya tersebut merupakan suatu bentuk promosi daerah yang dilakukan oleh Kabupaten Buleleng. Pemerintah Kabupaten Buleleng sudah beberapa kali menyelenggarakan berbagai event festival untuk meningkatkan kunjungan wisatawan salah satunya adalah Buleleng Festival.

Berdasarkan Data Dinas Pariwisata Kabupaten Buleleng, 2018 jumlah pengunjung Buleleng Festival Kabupaten Buleleng mengalami fluktuasi dengan total jumlah pengunjung 12.200 orang (99.98\%) dalam kurun waktu 5 (lima) tahun (Dinas Pariwisata Kabupaten Buleleng, 2018).

Penyelenggaraan Buleleng festival Kabupaten Buleleng selalu mengusung tema yang berbeda setiap tahunnya, berbagai pertunjukan seni dan budaya serta pameran kuliner khas daerah juga dihadirkan dalam kegiatan yang berlangsung dengan melibatkan 9 kecamatan di Kabupaten Buleleng tersebut.

Buleleng festival merupakan event festival budaya yang menyajikan kombinasi dan kolaborasi antara seni dan budaya, pendidikan serta lingkungan social yang akan mengarahkan pada Kabupaten Buleleng saling berintegrasi dalam pelestarian budaya, kreativitas dan inovasi masyarakat sehingga mengangkat branding Buleleng.

Banyaknya kegiatan event yang dilaksanakan di Kabupaten Buleleng tentu meningkatkan intensitas persaingan usaha pariwisata di bidang event menuntut para perencana dan pelaksana kegiatan event akan mampu 
menuangkan imajinasi yang kreatif, inovatif dalam menampilkan disain dan konsep event dengan memperhatikan servicescape dan kegiatan yang beranekaragam sehingga dapat menarik minat pengunjung.

Lingkungan fisik (servicescape) yang memiliki daya tarik tersendiri bagi konsumen atau pengunjung akan datang untuk mengunjungi kegiatan event Buleleng festival. Desain event yang kreatif dan inovatif akan menjadikan Buleleng festival memberikan nuansa yang unik dan berbeda dari event yang ada di daerah lain.

Menurut Lovelock dan Wirtz (2011:277) beberapa aspek terdapat dalam servicescape yaitu antara lain ambient condition (suasana, suhu udara, pencahayaan dan kebersihan lingkungan), spatial layout and functionality (tata letak ruangan, peralatan), sign, symbols and artifacts (lambang dan logo).

Buleleng festival merupakan kegiatan event budaya yang dilaksanakan di Kabupaten Buleleng seharusnya memperhatikan konsep dan disain yang kreatif untuk dapat menarik perhatian yang dapat mempengaruhi pengunjung untuk datang ke event Buleleng festival dan memberikan kepuasan bagi pengunjung.

Tidak dipungkiri bahwa dengan pengelolaan lingkungan fisik yang baik pada kegiatan event Buleleng festival, maka akan memberikan kepuasan bagi pengunjung untuk menikmati event budaya yang disuguhkan. Lingkungan fisik pada event Buleleng festival sebaiknya memberikan warna disain yang sesuai dengan tema event Buleleng festival, lingkungan disekitar event, tanda ataun petunjuk sehingga dengan mudah pengunjung untuk melihatnya pada saat berkunjung ke Buleleng festival.

Secara umum pengunjung ingin mendapatkan pengalaman liburan yang tidak pernah mereka rasakan di tempat lain, dengan demikian hal-hal fisik yang berada di lingkungan event Buleleng festival memiliki pengaruh penting di dalam memberikan kualitas jasa yang dipertujukkan, sehingga perlu diketahui kepuasan pengunjung berdasarkan kajian atau penelitian event Buleleng festival dilihat dari konsep servicescape. Penelitian ini bertujuan untuk mengetahui secara umum tentang perencanaan event festival dengan konsep disain kreatif atau konsep lingkungan fisik (servicescape) pada event Buleleng festival di Kabupaten Buleleng.

\subsection{Kajian Pustaka}

\subsubsection{Dimensi Lingkungan Fisik (servicescape)}

Lingkungan fisik merupakan fisik lingkungan atau fasilitas fisik dimana layanan tersebut di produksi, disampaikan dan dipengaruhi prilaku selama menggunakan jasa tertentu. Menurut Bitner dalam Lovelock (2011:12) membagi tiga dimensi servicescape yaitu: Kondisi lingkungan (ambient condition) merupakan karakteristik lingkunganyang berkenaan dengan lima panca indera, seperti suhu, pencahayaan, musik, warna dan gangguan suara. Tata ruang dan fungsi (spatial layout and functionality) merupakan denah ruangan, ukuran dan bentuk dari perlengkapan perabot yang berpotensi cara mereka diatur juga kemampuan benda-benda tersebut untuk memfasilitasi kegiatan transaksi jasa. Tanda, simbol dan artefak (sign, symbol and artefacts) merupakan tanda atau simbol yang mampu mengkomunikasikan penampilan bagi pelanggan, membantu pelanggan menemukan arahnya, dan untuk menyampaikan proses pelayanan jasa.

\subsubsection{Festival}

Definisi Festival menurut Getz (2007) adalah perayaan publik bertema, sedangkan menurut Falassi (1987) dalam Getz (2010) mengatakan bahwa festival sebagai kegiatan yang dilakukan secara berkala, berulang, acara sosial yang dilangsungkan melalui serangkaian 
acara terkoordinasi, untuk semua anggota dari seluruh masyarakat, disatukan oleh etnis, bahasa, obligasi sejarah dan sebagainya.

Menurut Noor

(2013:30)

mendefinisikan festival adalah suatu event yang dimiliki oleh sekelompok orang yang mengusung kekuasaan khusus, spirit, pengetahuan dan peningkatan adat kekeluargaan. Event jenis festival yang berkembang dari budaya biasanya membolehkan masyarakat dan pengunjung untuk terlibat langsung dalam kreasi yang diselenggarakan. Festival memiliki sifat yang sama dengan kehidupan, memiliki pengalaman khusus pada satu wilayah masyarakat yang belum tentu ada di daerah lain.

\subsubsection{Kepuasan Konsumen}

Kepuasaan pelanggan sering dipandang sebagai proses (processoriented approach). Hal ini tercermin pada beberapa definisi seperti proses evaluasi untuk memastikan bahwa pengalaman konsumsi setidaknya sebagus apa yang seharusnya didapatkan. Evaluasi bahwa alternatif yang dipilih konsisten dengan keyakinan awal terhadap alternatif bersangkutan. Respon konsumen pada evaluasi persepsi terhadap perbedaan terhadap ekspektasi awal (atau standar kinerja tertentu) dan kinerja aktual produk sebagaimana dipersepsikan setelah konsumsi produk (Tjiptono, 2015: 1718).

Menurut Sunyoto (2012:222), menyatakan kepuasan dibagi menjadi dua macam yaitu: kepuasan fungsional merupakan kepuasan yang diperoleh dari fungsi suatu produk yang dimanfaatkan, sedangkan kepuasan psikologikal merupakan kepuasan yang diperoleh dari atribut yang bersifat tidak terwujud dari produk. Jenis kepuasan yang diperoleh oleh konsumen atau konsumen sangat bergantung kepada pelayanan yang diberikan oleh penyedia produk/jasa. Semakin cepat penyedia produk/jasa merespon kebutuhan ataupun keluhan dari konsumen atau pelanggan. Maka dapat dikatakan bahwa tingkat kualitas pelayanan adalah menjadi kunci dari tercapainya kepuasan konsumen atau pelanggan.

\subsubsection{Pengaruh Lingkungan Fisik dengan Kepuasan Pengunjung}

Pengaruh lingkungan fisik

(servicescape) terhadap kepuasan konsumen merupakan pengaturan fasilitas fisik dalam layanan yang terjadi dan mempengaruhi persepsi konsumen dalam servicescape yaitu kualitas yang diraskan dan tingkat kepuasan (internal) serta perilaku sehungan dengan pembelian (eksternal).

Kepuasan pengunjung merupakan keseluruhan sikap yang ditunjukkan konsumen atas barang atau jasa setelah memperoleh dan menggunakannya.

Pada saat ini, tempat (venue) penyelenggaraan kegiatan event Buleleng festival di Kabupaten Buleleng, kondisi lingkungan banyak diminati oleh wisatawan mancanegara maupun wisatawan domestik, sehingga sangat penting dalam mempengaruhi lingkungan fisik dari kegiatan event Buleleng festival untuk membuat pengunjung mendapatkan pengalaman yang baik dan menyenangkan.

\section{METODE PENELITIAN}

Pada penelitian ini, untuk mengetahui pengaruh antara variabel bebas dengan variabel terikat, maka analisis regresi linier berganda dipergunakan untuk mengkaji dan menguji pengaruh variabel independen yaitu pada dimensi suasana, dimensi disain, dimensi sosial terhadap variabel dependen yaitu kepuasan pengunjung event Buleleng festival di Kabupaten Buleleng. Tujuannya adalah untuk mengistimasi nilai rata-rata variabel dependen berdasarkan nilai variable independen yang sudah diketahui. Data penelitian dikumpulkan melalui penyebaran kuesioner kepada pengunjung event Buleleng festival di kabupaten Buleleng yaitu sebanyak 90 
responden. Pernyataan-pernyataan pada kuesioner disusun dengan 5 pilihan, baik yang bersifat positif dengan pilihan 5 dan bersifat negatif dengan pilihan 1 berskala data ordinal yang menggunakan skala Likert (Sugiyono, 2013:93).

Hipotesis pada penelitian:

Ho:? = 0 Tidak ada pengaruh antara lingkungan fisik (servicescape) secara parsial dan simultan terhadap kepuasan pengunjung Buleleng festival di Kabupaten Buleleng

Ha: $\neq 0$ Ada pengaruh antara lingkungan fisik (servicescape) secara parsial dan simultan terhadap kepuasan pengunjung Buleleng festival di Kabupaten Buleleng

\section{3. ,HASIL DAN PEMBAHASAN 3.1 Karakteristik Responden}

Berdasarkan hasil penelitian yang telah dilakukan dari 90 responden, dilihat dari jenis kelamin bahwa sebagian besar wisatawan mancanegara yang telah berkunjung ke event Buleleng festival adalah pengunjung dengan jenis kelamin laki-laki, yaitu sebesar $57 \%$ dan wanita sebesar 43\%, hal tersebut memperlihatkan bahwa laki-laki lebih banyak melakukan aktifitas kegiatan wisata dibandingkan dengan wanita

Umur sangat mempengaruhi motivasi dalam melakukan perjalanan wisata dan berkunjung ke event Buleleng festival. Untuk melakukan kegiatan perjalanan dengan menempuh jarak yang cukup jauh (ke luar negeri), umur merupakan salah satu faktor penentu. dari 90 responden yang berkunjung ke event Buleleng festival, 53,3\% adalah pengunjung yang telah melakukan kegiatan perjalanan wisata yang tergolong pada usia produktif dan pada urutan kedua sebanyak $14,4 \%$ berusia 31 sampai 40 tahun. Untuk pengunjung yang masih berusia di bawah 20 tahun jumlahnya hanya 10\%, sedangkan pengunjung yang berada pada usia 41 sampai 50 tahun jumlahnya $14,4 \%$. Suatu hal yang sangat menarik dari pengamatan adalah pengunjung yang berusia 50 tahun ke atas (berusia lanjut) masih berkeinginan untuk melakukan kegiatan wisata air yang jumlahnya mencapai 8,9\%.

Jumlah pengunjung yang berpendidikan tinggi (universitas dan diploma) menempati urutan paling tinggi yaitu $45,5 \%$ telah mendapat gelar S1, dan, 30\% memiliki gelar diploma, kemudian disusul dengan yang berpendidikan menengah atau sederajat sebanyak $21,1 \%$ dan 3,3\% memiliki gelar pasca sarjana. Dari data tersebut dapat dikatakan bahwa pengunjung yang berpendidikan tinggilah yang banyak melakukan aktifitas perjalanan wisata.

Karakteristik responden berdasarkan pekerjaan memperlihatkan bahwa sebagian besar responden yang berkunjung ke event Buleleng festival $(23,3 \%)$ mempunyai pekerjaan sebagai tenaga ahli/professional. Sebanyak $37,7 \%$ merupakan wirausaha, $18,9 \%$ merupakan pegawai swasta, dan 5\% merupakan pegawai negeri. Pelajar dan mahasiswa sebesar $12,2 \%$. Selain bekerja sebagai pegawai atau karyawan swasta, dari seluruh responden 4,4\% wisatawan tidak bekerja, akan tetapi mereka memiliki profesi lain seperti pensiunan, tenaga sukarela, dan bahkan ada yang tidak memiliki pekerjaan.

\subsection{Variabel Penelitian}

Kuesioner dikatakan valid apabila pertanyaan yang disampaikan mampu mengungkap sesuatu yang akan diukur oleh kuesioner tersebut (Pratisto, 2007:45). Indikator untuk mengukur variabel dalam penelitian ini memiliki nilai korelasi yang lebih besar dari 0,207. Variabel dimensi suasana atau kondisi sekitar (X1), dimensi disain atau ruang dan fungsi (X2), dimensi sosial (X3) dan kepuasan pengunjung $(\mathrm{Y})$ dengan nilai rhitung ? 0,207 dan semuanya bernilai positif, sehingga dapat disimpulkan bahwa semua indikator pernyataan yang diujikan adalah valid dan dapat digunakan untuk pengujian selanjutnya. variabel yang dianalisis mempunyai 
koefisien alpha yaitu di atas 0,60. Variabel dimensi suasana atau kondisi sekitar (X1), dimensi disain (X3) dan dimensi social (X3) dan kepuasan pengunjung (Y) memiliki nilai crombach's alpha lebih dari 0,60. Dapat disimpulkan bahwa kuesioner yang digunakan dalam penelitian ini merupakan kuesioner yang handal dan dapat dipercaya.

\subsection{Analisis Regresi Linier Berganda}

Analisis regresi berganda untuk memprediksi nilai pengaruh dua variable bebas atau lebih terhadap variable terkat untuk membuktikan ada tidaknya hubungan fungsi atau hubungan kausal antara dua variable bebas atau lebih dengan satu variable terikat (Riduwan, 2007:108).

Analisa regresi linier berganda merupakan analisis yang digunakan untuk mengetahui pengaruh variabel dimesi suasana (X1), dimensi disain (X2) dan dimensi sosial (X3) terhadap kepuasan pengunjung Buleleng festival di Kabupaten Buleleng (Y).

Berdasarkan hasil analisis, maka dapat dilihat bentuk persamaan regresi linier berganda dalam hubungan lingkungan fisik (servicescape) terhadap kepuasan pengunjung event Buleleng festival dapat dituliskan sebagai berikut:

$\mathrm{Y}=0,912+0,056+0,101+0,302+$ ?

Interpretasi dari persamaan regresi tersebut adalah:

1) Nilai konstanta sebesar regresi sebesar 0,912 menunjukkan bahwa kepuasan pengunjung (Y) akan bernilai 0,912 poin apabila variabel dimensi suasana, dimensi disain dan dimensi sosial bernilai 0 .

2) Nilai koefisien regresi variable dimensi suasana (X1) memiliki nilai sebesar 0,056. Angka 0,056 menunjukkan bahwa kepuasan pengunjung $(\mathrm{Y})$ akan meningkat sebesar 0,056 apabila variabel lain yaitu dimensi disain dan dimensi sosial bernilai 0 atau konstanta. Tanda postitif (+) menunjukkan bahwa variabel dimensi suasana (X1) memiliki pengaruh yang searah terhadap kepuasan pengunjung (Y). Jika variabel produk naik sebesar 1 satuan maka nilai keputusan pembelian yang dihasilkan akan naik sebesar 0,056 poin dan juga sebaliknya apabila nilai produk berkurang sebesar 1 satuan maka nilai kepuasan pengunjungpun akan berkurang sebesar 0,056 .

3) Nilai koefisien regresi variabel dimensi disain (X2) memiliki nilai sebesar 0,101. Angka 0,101 menunjukkan bahwa kepuasan pengunjung (Y) akan meningkat sebesar 0,101 apabila variabel lain yaitu produk dan harga bernilai 0 atau konstanta. Tanda postitif (+) menunjukkan bahwa variabel dimensi disain (X2) memiliki pengaruh yang searah terhadap kepuasan pengunjung (Y). Jika variabel dimensi disain naik sebesar 1 satuan maka nilai kepuasan pengunjung yang dihasilkan akan naik sebesar 0,101 poin dan juga sebaliknya apabila nilai dimensi disain berkurang sebesar 1 satuan maka nilai kepuasan pengunjung pun akan berkurang sebesar 0,101.

4) Nilai koefisien regresi variabel dimensi sosial (X3) memiliki nilai sebesar 0,302. Angka 0,302 menunjukkan bahwa kepuasan pengunjung (Y) akan meningkat sebesar 0,302 apabila variabel lain yaitu dimensi suasana dan dimensi disain bernilai 0 atau konstanta. Tanda postitif (+) menunjukkan bahwa variabel dimensi social (X3) memiliki pengaruh yang searah terhadap kepuasan pengunjung $(\mathrm{Y})$. Jika variabel dimensi sosial naik sebesar 1 satuan maka nilai kepuasan pengunjung yang dihasilkan akan naik sebesar 0,302 poin dan juga sebaliknya apabila nilai dimensi sosial berkurang sebesar 1 satuan maka nilai kepuasan pengunjung pun akan berkurang sebesar 0,302. 
Uji $\mathrm{F}$ dilakukan untuk mengetahui pengaruh varibel dimensi suasana (X1), dimensi disain (X2) dan dimensi sosial (X3) terhadap kepuasan pengunjung Buleleng festival di Kabupaten Buleleng (Y). Pengaruh keseluruhan variabel secara simultan akan dilihat dari besarnya nilai Fhitung yang didapatkan dan kemudian dibandingkan dengan Ftabel. Berdasarkan hasil nilai Ftabel yaitu 2,711 dan nilai Fhitung yaitu 32,310 . Nilai Fhitung > Ftabel $(32,310>$ 2,711) dan signifikan Fhitung ? 0,05 $(0,000$ ? 0,05), maka Ho ditolak dan $\mathrm{Ha}$ diterima.

\subsection{Analisis Koefisien Determinasi (R2)}

Berdasarkan hasil yang diperoleh dengan bantuan SPSS versi 20, maka didapatkan nilai adjusted R square (R2) adalah 0,530. Dari nilai tersebut dihitung koefisien determinasinya yaitu $0,530 \mathrm{x}$ $100 \%=53,0$ persen. Dari hasil tersebut diketahui bahwa lingkungan fisik (servicescape) secara bersama-sama mempengaruhi kepuasan pengunjung Buleleng festival di Kabupaten Buleleng sebesar 53,0 persen dikatagorikan sedang, selebihnya yaitu 47,0 persen merupakan kepuasan pengunjung Buleleng festival yang dipengaruhi oleh factor-faktor lain yang tidak diteliti.

\section{KESIMPULAN}

Berdasarkan pada hasil penelitian yang telah dilakukan, dapat disimpulkan sebagai berikut:

1) Terdapat hubungan positif antara dimensi suasana, disain dan dimensi sosial terhadap kepuasan pengunjung event Buleleng festival secara parsial di Kabupaten Buleleng. Hubungan antara variabel dimensi suasana terhadap kepuasan pengunjung memiliki hubungan yang sedang dengan nilai koefisien korelasi sebesar 0,570 dan signifikansi 0,000 hubungan antara dimensi disain terhadap kepuasan pengunjung memiliki hubungan yang sedang dengan nilai koefisien sebesar 0,477 dan signifikan 0,000 hubungan antara dimensi social terhadap kepuasan pengunjung memiliki hubungan yang kuat dengan nilai koefisien korelasi sebesar 0,617 dan signifikansi 0,000.

2) Terdapat hubungan positif antara dimensi suasana, disain dan dimensi sosial terhadap kepuasan pengunjung event Buleleng festival secara simultan di Kabupaten Buleleng. Hubungan antara variabel dimensi suasana, disain dan dimensi sosial terhadap kepuasan pengunjung memiliki hubungan yang kuat dengan nilai koefisien korelasi sebesar 0,728.

3) Terdapat hubungan positif signifikan yang kuat antara dimensi suasana, disain dan dimensi sosial terhadap kepuasan pengunjung event Buleleng festival di Kabupaten Buleleng. Secara parsial dimensi suasana (thitung > ttabel $/ 3,732>1,988$ ), disain (thitung $>$ ttabel / 2,463 > 1,988), dan dimensi sosial (thitung $>$ ttabel/ 4,564 > 1,988). Dimensi suasana, disain dan dimensi sosial juga berpengaruh secara simultan terhadap kepuasan pengunjung event Buleleng festival (Fhitung > Ftabel $/ 32,310>2,711$ ). Dan hal ini juga menandakan bahwa dimensi suasana, disain dan dimensi social berpengaruh secara signifikan dan searah terhadap kepuasan pengunjung event Buleleng festival di Kabupaten Buleleng.

Sehubungan dengan simpulan tersebut, rekomendasi disampaikan kepada pengelola Buleleng festival adalah event Buleleng festival sebaiknya selalu menperhatikan dimensi disain seperti tanda dan simbol dengan cara menampilkan arsitektur budaya Bali yang menarik, petunjuk arah menuju ke venue atau tempat berlangsungnya kegiatan event Buleleng festival sehingga pengunjung dapat melihat dengan lebih jelas. 
Wirata

DAFTAR PUSTAKA

Getz, Donald, 1997. Event Management \& Event Tourism, Cognizant Communication Corporation, New York.

Lovelock, Christopher., et. Al. (2011). Pemasaran Jasa: Manusia, Teknologi, Strategi Jilid 1 -7/E. Jakarta: Erlangga.

Noor, Any, 2009. Manajemen Event. Bandung: Alfabeta.

Riduwan, 2007. Pengantar Statistika. Bandung: Alfabeta.

Sugiyono. 2013. Metode penelitian Kuantitatif, Kualitatif dan R\&D. Bandung: Alfabeta.

Sunyoto, Danang. 2012. Konsep Dasar Pemasaran dan Prilaku Konsumen. Yogyakarta: CAPS (Center of Academic Publising Service).

Pratisto, Arif. 2007. Statistik Menjadi Mudah dengan SPSS. Jakarta: PT. Elex Media Komputindo.

Tjiptono, Fandi dan Anastasia, Diana. 2015. Pelanggan Puas? Tidak Cukup! Yogyakarta: CV Andi Offset.

Tjiptono, F. 2016. Pemasaran Jasa. Bayu Media Publishing: Jawa Timur. 